\title{
A 2 year histopathological audit for non-oncological hysterectomies in a tertiary care hospital
}

\author{
Salma Bhat*, Nazia Bhat, Isma Niyaz, Rohi Wani
}

Department of Pathology, Government Medical College, Srinagar, Jammu and Kashmir, India

Received: 02 June 2017

Accepted: 29 June 2017

*Correspondence:

Dr. Salma Bhat,

E-mail: bhatdrsalma@gmail.com

Copyright: (C) the author(s), publisher and licensee Medip Academy. This is an open-access article distributed under the terms of the Creative Commons Attribution Non-Commercial License, which permits unrestricted non-commercial use, distribution, and reproduction in any medium, provided the original work is properly cited.

\begin{abstract}
Background: Hysterectomy is the most common gynecological surgery in the world and is considered to be the most definitive treatment option for various diseases like DUB (dysfunctional uterine bleeding), leiomyoma, adenomyosis, chronic pelvic pain, prolapse, and malignancy. The aim of the study was to evaluate the surgical indications, routes of surgery and the correlation between preoperative diagnosis and histopathological examination of hysterectomy specimens

Methods: This was a retrospective audit. The pre-operative diagnosis and histopathologic data of all consecutive specimens of hysterectomies were collected and analysed. Those with confirmed malignancy before operation were excluded. All elective as well as emergency hysterectomies (including obstetric hysterectomies) were analyzed. Preoperative indications were compared with the final histopathological report.

Results: Most common indication for hysterectomy was symptomatic fibroid uterus followed by utero-vaginal prolapse and obstetric causes. Overall, there was no pathology identified in approximately $50 \%$ of all hysterectomies received in our department.

Conclusions: Proper audit and review can help in improving the quality of health care in our country. The results of our study may help to reduce inappropriate indications for hysterectomy.
\end{abstract}

Keywords: Audit, Histopathologic, Hysterectomies

\section{INTRODUCTION}

Hysterectomy is the most common gynecological surgery in the world and is considered to be the most definitive treatment option for various diseases like DUB (dysfunctional uterine bleeding), leiomyoma, adenomyosis, chronic pelvic pain, prolapse, and malignancy. ${ }^{1}$ However, with advent of effective medical and conservative treatment options for non-oncological causes it is now posing a question mark about the indications, probable overuse and justification of hysterectomy. It continues to be debatable owing to psychosocial, emotional, economic, sexual, and medical significance to women. ${ }^{2}$ In a study conducted in USA by Broder et al. indications for nononcological and nonemergency hysterectomies were found to be inappropriate. ${ }^{3}$ Therefore, regular audit is required to assess the correlation between preoperative diagnosis and histopathological examination of specimen for justification of the procedure

The aim of the study was to evaluate the surgical indications, routes of surgery and the correlation between preoperative diagnosis and histopathological examination of hysterectomy specimens. 


\section{METHODS}

This was a retrospective audit. The pre-operative diagnosis and histopathologic data of all consecutive specimens of hysterectomies received in the Department of Pathology, Government Medical College and Hospital, Srinagar, Jammu and Kashmir India from January 2014 to January 2016 were collected and analysed. Those with confirmed malignancy before operation were excluded. All elective as well as emergency hysterectomies (including obstetric hysterectomies) were analyzed. Preoperative indications were compared with the final histopathological report. Preoperative indications were recorded from the histopathological requisition form. Hysterectomy was considered justified if pathology report verified the indication for surgery or had significant pathology. Only descriptive statistics were used to infer results.

\section{RESULTS}

A total of 496 hysterectomies were received in our department out of which $455(91.7 \%$ ) were abdominally performed and $41(8.2 \%)$ hysterectomies were vaginally performed. The mean age at hysterectomy was 46.6 years and the majority of women who underwent hysterectomy were in their fourth and fifth decades (78\%).

Most common indication for hysterectomy was symptomatic fibroid uterus $(n=235)$ [47.37\%], followed by utero-vaginal prolapse $(n=125)[25.20 \%]$ and obstetric causes $(n=28)$ [5.64\%]. Less common indications being adenomyosis, endometriosis, endometrial hyperplasia, cervical intraepithelial neoplasia, chronic endometritis and granulomatous tubo-ovarian mass (Table 1).

Table 1: Distribution of hysterectomies according to age group, route of surgery and indications.

\begin{tabular}{|c|c|c|c|}
\hline Age group & Number of cases & Type of hysterectomy & Indications with $\%$ distribution \\
\hline$\leq 30$ years & 28 & $\begin{array}{l}\text { TAH (10) } \\
\text { Subtotal hysterectomy (18) }\end{array}$ & $\begin{array}{l}\text { Obstetric }(71.44 \%) \\
\text { Leiomyoma }(14.28 \%) \\
\text { DUB }(14.28 \%)\end{array}$ \\
\hline $31-40$ years & 125 & $\begin{array}{l}\text { TAH (33) } \\
\text { TAH with salpingo- } \\
\text { oophorectomy (90) } \\
\text { Subtotal hysterectomy (2) }\end{array}$ & $\begin{array}{l}\text { Leiomyoma }(75.2 \%) \\
\text { Obstetric }(6.4 \%) \\
\text { Endometriosis }(4 \%) \\
\text { DUB }(14.4 \%)\end{array}$ \\
\hline $41-50$ years & 139 & $\begin{array}{l}\text { TAH (55) } \\
\text { TAH with salpingo- } \\
\text { oophorectomy (76) } \\
\text { Vaginal hysterectomy (8) }\end{array}$ & $\begin{array}{l}\text { Leiomyoma }(82 \%) \\
\text { Prolapse }(5.75 \%) \\
\text { Simple non-atypical hyperplasia }(0.71 \%) \\
\text { Complex hyperplasia with atypia }(0.71 \%) \\
\text { DUB }(10.79 \%)\end{array}$ \\
\hline 51-60 years & 114 & $\begin{array}{l}\text { TAH with salpingo- } \\
\text { oophorectomy ( } 86) \\
\text { Vaginal hysterectomy (28) }\end{array}$ & $\begin{array}{l}\text { Prolapse }(46.49 \%) \\
\text { Leiomyoma }(42.10) \\
\text { Simple non-atypical hyperplasia }(4.38 \%) \\
\text { Endometritis }(1.75 \%) \\
\text { DUB }(5.26 \%)\end{array}$ \\
\hline$\geq 60$ years & 90 & $\begin{array}{l}\text { Vaginal hysterectomy ( } 58) \\
\text { TAH with salpingo- } \\
\text { oophorectomy (30) }\end{array}$ & $\begin{array}{l}\text { Prolapse }(71.11 \%) \\
\text { Leiomyoma }(10 \%) \\
\text { Simple non-atypical hyperplasia }(4.44 \%) \\
\text { CIN III }(1.11 \%) \\
\text { Granulomatous tubo-ovarian mass }(1.11 \%) \\
\text { Complex hyperplasia with atypia }(1.11 \%) \\
\text { DUB }(11.11 \%)\end{array}$ \\
\hline
\end{tabular}

In the first category of age $\leq 30$ years, total number of hysterectomies were 28 . The most common preoperative indications were emergency obstetrical causes like placenta previa, placenta increta and placenta accreta.

In second category of age group 31-40 years, a total number of hysterectomies were 125 , main pathologies in this group being leiomyoma followed by obstetric causes. In 41-50-year age group, leiomyoma was the commonest indication for hysterecyomy. In this group, no significant pathology was seen in 15 cases. The most common indication for hysterectomy in 5-1-60 year age group was prolapse followed by leiomyoma and simple non-atypical hyperplasia. In the age group of $>60$ years, hysterectomy was done for prolapse in $72.7 \%$ of all cases in this group.

Overall, there was no pathology identified in approximately $50 \%$ of all hysterectomies received in our department. 


\section{DISCUSSION}

Hysterectomy is the most common gynecological surgery in the world providing definitive cure to many diseases like DUB, leiomyoma, adenomyosis, endometriosis, pelvic inflammatory disease, prolapse, and malignancy. ${ }^{1}$ Studies that have addressed issues of satisfaction rates and quality of life have shown hysterectomy to be a profoundly effective operation. ${ }^{4}$

An audit to evaluate the indications for hysterectomy with the histopathologic findings can help recognize probable overuse, justification of hysterectomy or nonavailability of newer alternatives for hysterectomy. The histopathological reporting of all hysterectomies is mandatory and the audit results would help recognize the need for implementing more efficient and cost-effective alternatives to hysterectomy tailored to the individual needs of the patients.

A total of 496 hysterectomies were received in our department. Women who underwent hysterectomy were in their fourth and fifth decades of life with a mean of 46.6 years. Hysterectomy was commonest among the age group 40 - 49 years which constituted $54.6 \%$ of the total hysterectomies performed at a teaching hospital at Kano, Nigeria. ${ }^{5}$ Most of these were abdominal (91.7\%) hysterectomies followed by vaginal $(8.2 \%)$. Types of hysterectomy procedures followed in our study were TAH with salpingoopherectomy 257/496 (51.81\%) followed by TAH 116/496 (23.38\%) and vaginal hysterectomy $(18.95 \%)$. In a study by Bala et al more than $90 \%$ of the hysterectomies were done by abdominal route. ${ }^{6}$ Total abdominal hysterectomy accounted for $82.7 \%$ of hysterectomies in another study. ${ }^{7} \mathrm{TAH}$ with salpingoopherectomy superseded TAH and vaginal hysterectomies in various other studies. ${ }^{3,7}$

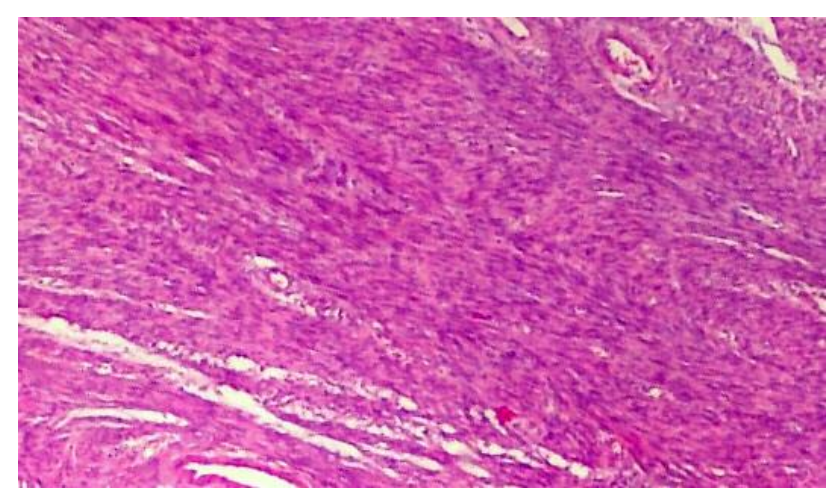

Figure 1: Leiomyoma showing a fascicular pattern of smooth muscle bundles separated by well vascularized connective tissue.

Most common indications for hysterectomy in our study were symptomatic fibroid uterus (Figure 1) followed by utero-vaginal prolapse. The same indications topped the list of indications for hysterectomies in varied studies..$^{9-11}$ The highlighting aspect of our study was the alarmingly high percentage of emergency obstetric hysterectomies (EOH). EOH constituted $5.64 \%$ of all hysterectomies in our study. EOH comprised $0.52 \%, 0.06 \%$ and $0.51 \%$ of all hysterectomies in studies from India, US and Nigeria respectively. ${ }^{12-14}$

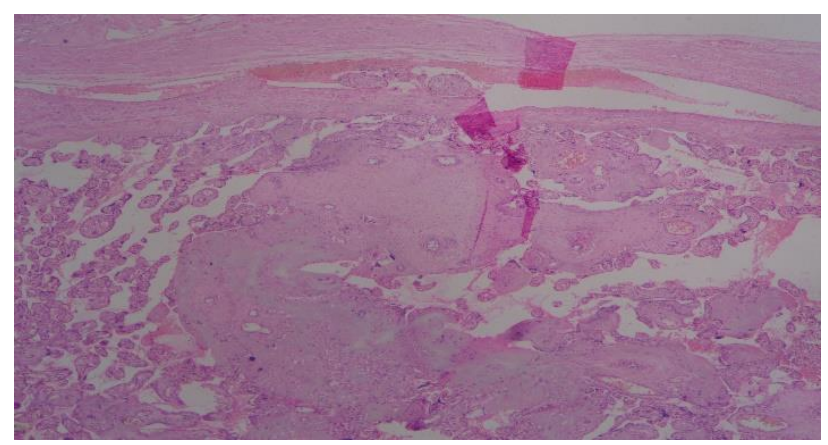

Figure 2: Chorionic villi penetrating through myometrium upto the serosa.

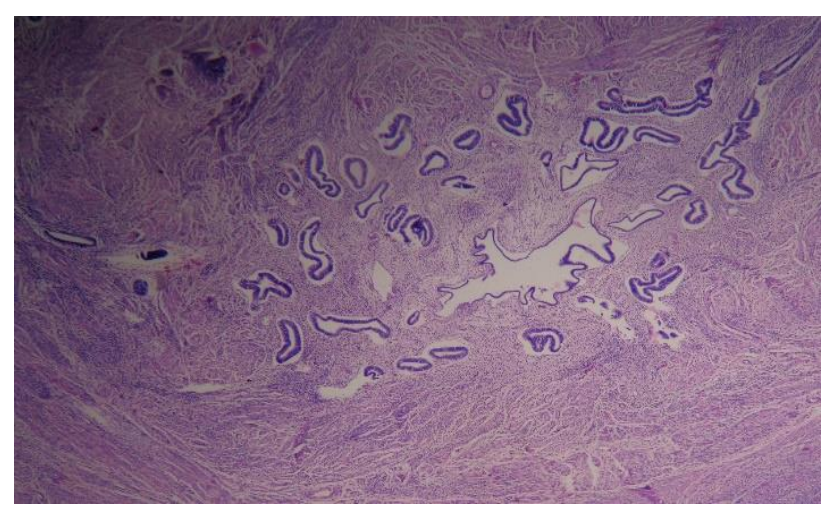

Figure 3: Uterine adenomyosis.

Morbidly adherent placenta (Figure 2) and ruptured uterus were the common indications. Ruptured uterus, morbidly adherent placenta and atonic PPH topped the list of indications for EOH in a study by Shirodker SD et al. ${ }^{15}$ Adenomyosis was the most common finding missed preoperatively (Figure 3 ). Hyperplasias, both simple nonatypical and complex atypical hyperplasias were seen at 45 years and above age groups (Figure 4 ).

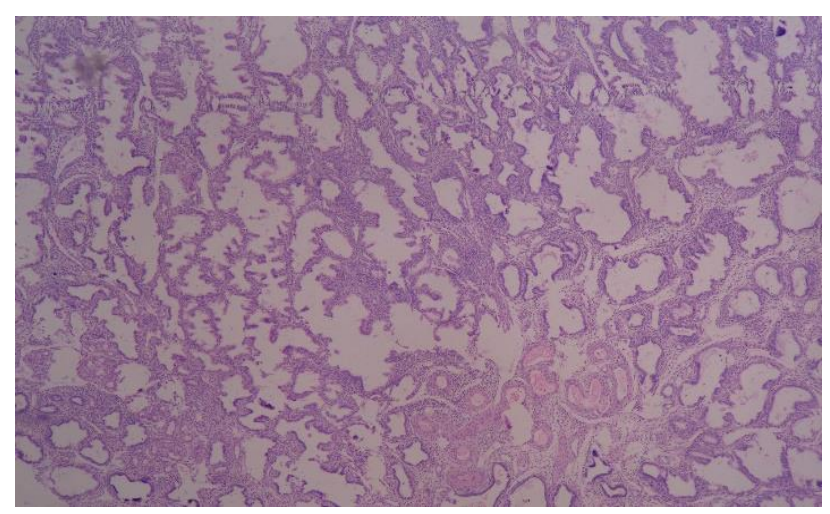

Figure 4: Simple non-atypical hyperplasia of endometrial glands. 
Our audit included comparison of preoperative diagnosis with histopathological examination of specimens. In more than $50 \%$ cases the preoperative clinical diagnosis was DUB and no significant pathology was identified on histopathology.

\section{CONCLUSION}

Proper audit and review can help in improving the quality of health care in our country. The results of our study may help to reduce inappropriate indications for hysterectomy. With the emergence of varied conservative approaches to deal with benign gynecological conditions, it is imperative to discuss available options with the patient before taking a final decision of surgically removing her uterus.

Funding: No funding sources

Conflict of interest: None declared

Ethical approval: The study was approved by the Institutional Ethics Committee

\section{REFERENCES}

1. Gupta G, Kotasthane DS, Kotasthane VD. Hysterectomy: a clinico-pathological correlation of 500 cases. Int J Gynecol Obstet. 2009;14(1):1-5

2. Magon N, Chahuan M. Editorial. Subtotal Hysterectomy: has it come a full circle?. Int J Clin Cases Investigations. 2012;4:1-4.

3. Broder MS, Kanouse DE, Mittman BS, Bernstein SJ. The appropriateness of recommendations for hysterectomy. Obstet Gynecol. 2000;95(2):199-205.

4. Bhattacharya S, Middleton LJ, Tsourapas A, Lee AJ, Champaneria R, Daniels JP, et al. Hysterectomy, endometrial ablation and Mirena ${ }^{\circledR}$ for heavy menstrual bleeding: A systematic review of clinical effectiveness and cost-effectiveness analysis. Health Technol Assess. 2011;15:1-252.

5. Bala R, Devi KP, Singh CM. Trend of hysterectomy: A retrospective analysis in Regional Institute of Medical Sciences (RIMS). J Med Soc. 2015;29:4-7.

6. Aksu F, Gezer A, Oral E. Seventeen-year review of hysterectomy procedures in a university clinic in
Istanbul 1985-2001. Arch Gynecol Obstet. 2004;270(4):217-22.

7. Pandey D, Sehgal K, Saxena A, Hebbar S, Nambiar J, Bhat RG. An audit of indications, complications, and justification of hysterectomies at a teaching hospital in India. Int J Reprod Med. 2014;2014.

8. Leung PL, Tsang SW, Yuen PM. An audit on hysterectomy for benign diseases in public hospitals in Hong Kong. Hong Kong Med J. 2007;13(3):18793.

9. Sucheta KL, Manangi M, Madhu KP, Arun BJ, Nagaraj N. Hysterectomy: clinical profile, indications and postoperative complications. Int $\mathbf{J}$ Reprod Contracept Obstet Gynecol. 2016;5:2093-6.

10. Shaikh TA, Memon F, Memon Z. Hysterectomies; an audit at a tertiary care hospital. Professional Med J. $2011 ; 18(1)$.

11. Juneja SK, Tandon P, Mohan B, Kaushal S. A change in the management of intractable obstetrical hemorrhage over 15 years in a tertiary care center. Int J Appl Basic Med Res. 2014;4(Suppl 1):S17-S19.

12. Bodelon C, Bernabe-Ortiz A, Schiff MA, Reed SD. Factors associated with peripartum hysterectomy. Obstet Gynecol. 2009;114(1):115-23.

13. Nwobodo E, Nnadi D. Emergency obstetric hysterectomy in a tertiary hospital in sokoto, Nigeria. Ann Med Health Sci Res. 2012;2(1):37-40.

14. Shirodker SD, Pandey A, Yadav S. Emergency obstetric hysterectomy: review at a tertiary care hospital. Int J Reprod Contracept Obstet Gynecol. 2016;5:3811-4.

15. Tiwana KK, Nibhoria S, Monga $T$, Phutela R. Histopathological audit of 373 nononcological hysterectomies in a teaching hospital. Pathol Res Int. 2014;2014.

Cite this article as: Bhat $\mathrm{S}$, Bhat N, Niyaz I, Wani R. A 2 year histopathological audit for nononcological hysterectomies in a tertiary care hospital. Int J Reprod Contracept Obstet Gynecol 2017;6:3260-3. 